Article

\title{
3-D CFD Modeling for Parametric Study in a 300-MWe One-Stage Oxygen-Blown Entrained-Bed Coal Gasifier
}

\author{
Sang Shin Park, Hyo Jae Jeong and Jungho Hwang* \\ Department of Mechanical Engineering, Yonsei University, Seoul 120-749, Korea; \\ E-Mails: pss7544@hanmail.net (S.S.P.); jeonghyojae@yonsei.ac.kr (H.J.J.) \\ * Author to whom correspondence should be addressed; E-Mail: hwangjh@yonsei.ac.kr; \\ Tel.: +82-2-2123-2821; Fax: +82-2-312-2821.
}

Academic Editor: Mehrdad Massoudi

Received: 16 March 2015 / Accepted: 5 May 2015 / Published: 11 May 2015

\begin{abstract}
Three-dimensional computational fluid dynamics (CFD) modeling of the gasification performance in a one-stage, entrained-bed coal gasifier (Shell Coal Gasification Process (SCGP) gasifier) was performed, for the first time. The parametric study used various $\mathrm{O}_{2} /$ coal and steam/coal ratios, and the modeling used a commercial code, ANSYS FLUENT. CFD modeling was conducted by solving the steady-state Navier-Stokes and energy equations using the Eulerian-Lagrangian method. Gas-phase chemical reactions were solved with the Finite-Rate/Eddy-Dissipation Model. The CFD model was verified with actual operating data of Demkolec demo Integrated Gasification Combined Cycle (IGCC) facility in Netherlands that used Drayton coal. For Illinois \#6 coal, the CFD model was compared with ASPEN Plus results reported in National Energy Technology Laboratory (NETL). For design coal used in the SCGP gasifier in Korea, carbon conversion efficiency, cold gas efficiency, temperature, and species mole fractions at the gasifier exit were calculated and the results were compared with those obtained by using ASPEN Plus-Kinetic. The optimal $\mathrm{O}_{2} /$ coal and steam/coal ratios were 0.7 and 0.05 , respectively, for the selected operating conditions.
\end{abstract}

Keywords: one-stage; entrained-bed coal gasifier; SCGP gasifier; CFD; ASPEN Plus 


\section{Introduction}

Environmental and fuel supply concerns are driving the demand to develop more efficient uses of fossil fuel by energy industries. Therefore, efforts are being made to employ Integrated Gasification Combined Cycle (IGCC) processes rather than conventional or super critical Rankine-based cycles, which would also benefit the increased use of hydrogen fuel. The use of coal in IGCC is a promising alternative to combustion and is already commercially cost-competitive in many locations [1-4]. Gasification occurs when insufficient oxidant is supplied; the amount of oxygen supplied for coal gasification is usually $1 / 3$ to $1 / 5$ of that supplied for complete combustion [5].

Currently, commercial coal gasification technologies are classified by the feed flow pattern in the gasifier, such as fixed-, fluidized-, and entrained-bed gasification technologies [6]. Entrained-bed gasifiers have higher fuel conversion rates and shorter solid residence times than other gasifiers because the feedstock particles are usually ground to smaller than $1 \mathrm{~mm}$ [7].

Although entrained-bed gasifiers have become available through a number of demonstration projects, information on commercial coal gasifiers is restricted. Therefore, a technical understanding should be developed independently. Empirically characterizing any gasification process is difficult because of the high heating rate and short residence time, so numerical simulations are one of the most important tools used by universities and institutes, such as the United States Department of Energy (DOE), to advance gasification technology [8]. Computational fluid dynamics (CFD) analysis provides predictions of fluid flow and species concentrations in the gasifier while considering the reactor geometry and operating conditions [9]. While CFD is definitely required to design and operate the gasifier reactor and the burners, simplified models (or reduced order models) are used to simulate the overall gasification process and to integrate the process with the power plant [10-13].

CFD analysis has been carried out by many researchers to understand gasification reactions [14-23]. Chen et al. [14] performed CFD modeling of a 200-ton/day, two-stage, air-blown, entrained-bed gasifier (Mitsubishi Heavy Industry, Fukushima, Japan). Watanabe and Otaka [15] carried out a numerical simulation of the gasification reaction in the Central Research Institute of Electric Power Industry (CRIEPI)'s 2-ton/day, research-scale, coal gasifier by using a commercial CFD code, CFX-4, with a User FORTRAN interface. Slezak et al. [16] developed a comprehensive three-dimensional model to simulate a 2423-ton/day E-Gas coal gasifier using ANSYS FLUENT. Sun et al. [17] developed a three-dimensional numerical model to simulate a 2000-ton/day, industrial, opposed multiburner (OMB), coal-water slurry, entrained-bed gasifier at the East China University of Science and Technology (ECUST) in China by using ANSYS FLUENT. Luan et al. [18] developed a three-dimensional numerical model of a 2230-ton/day E-Gas coal gasifier by using ANSYS FLUENT. Kumar and Ghoniem [19,20] described the construction, validation, and application of a multi-scale model of entrained flow gasification. While the validation of the turbulence and particle turbulent dispersion submodels was focused on Kumar and Ghoniem [19], the impact of suggested improvements in these submodels on the predictions of key output parameters was analyzed through appropriate sensitivity analyses in Kumar and Ghoniem [20]. Abani and Ghoniem [21] investigated multi-phase reacting flow in a coal-fed entrained flow gasifier using large-eddy simulations (LES) and Reynolds-averaged Navier-Stokes (RANS) models. Seggiani [22] performed simulation for slag accumulation and flow on walls in a Prenflo coal gasifier using a slag building simplified model. Ye et al. [23] investigated the 
detailed flow and heat transfer characteristics in the quench pipe and transfer duct of the Taean 300 MWe IGCC process using CFD. Turbulent mixing and heat transfer by the hot syngas and quench gas streams were analyzed.

Most of these CFD studies analyzed E-Gas coal gasifiers, and no public results have been reported for a Shell coal gasification process (SCGP) gasifier except two papers published by our group [24,25]. In Hong et al. [24], a slag building simplified model was developed to determine wall heat flux of a Shell 300 MW coal gasifier. In the model, 4 layers (particulate, sintered, molten slag, solidified slag) were considered and mass conservation and energy balance were used to obtain each slag layer's thickness and surface temperature. Thermo-chemical and fluid characteristics of the gasifier were studied with and without considering the slag model using commercial CFD code FLUENT. In Hong et al. [25], the efficiency and characteristics of the SCGP gasifier were predicted using CFD simulation for different biomass-coal blending ratios. In their study, kinetic parameters obtained by char- $\mathrm{CO}_{2}$ gasification experiments were used for the 3D-simulation. In Korea, a national project for constructing a 300 MWe IGCC demonstration plant has been going on. The Korea Western-Power Company and DOOSAN Heavy Industries and Construction Company (Taean, Korea) selected the SCGP gasifier type. In this paper, a comprehensive three-dimensional, full-scale CFD analysis of the SCGP gasifier was carried out with ANSIS FLUENT 14.0. For the CFD analysis, a numerical model suggested by Jeong et al. [26] was used. They performed CFD modeling of an E-Gas gasifier and validated the model by comparing calculated results with operating data of the Wabash plant in the United States and also with those of Ma and Zitney [27].

In this study, various $\mathrm{O}_{2} /$ coal and steam/coal ratios were used to predict optimal operation conditions of the SCGP gasifier. The CFD model was verified with actual operating data of Demkolec demo IGCC facility in Netherlands that used Drayton coal. For Illinois \#6 coal, the CFD model was compared with ASPEN Plus results reported in NETL. For design coal used in the SCGP gasifier in Korea, carbon conversion, cold gas efficiencies, temperature, and species mole fractions at the gasifier exit were calculated and the results were compared with those obtained by using ASPEN Plus-Kinetic.

\section{The SCGP Gasifier and Coals}

The specific dimensions of the SCGP gasifier are confidential, so the geometry of the gasifier was simplified. The geometry of the gasifier is described in Figure $1[9,11]$. Pulverized coal and nitrogen as a transport gas were injected into the gasifier through the center hole of each burner in partial oxidation conditions. At the same time, a mixture of oxygen and steam was blown through the surrounding holes. In this study, it was assumed that all the reactants were injected together into the gasifier through the center hole of each burner. It was also assumed that the reactants were injected toward the center of the gasifier cross-section from four burners located at four corresponding inlets.

Drayton coal and Illinois \#6 coal were used to compare calculated results with actual operating data from Demkolec demo IGCC facility and analysis data from a report of NETL, respectively. After verifying the numerical model, the design coal of the SCGP gasifier in Korea was used for the CFD analysis. Proximate, ultimate analysis, higher heating value (HHV), and feeding rate for each coal are provided in Table 1. 


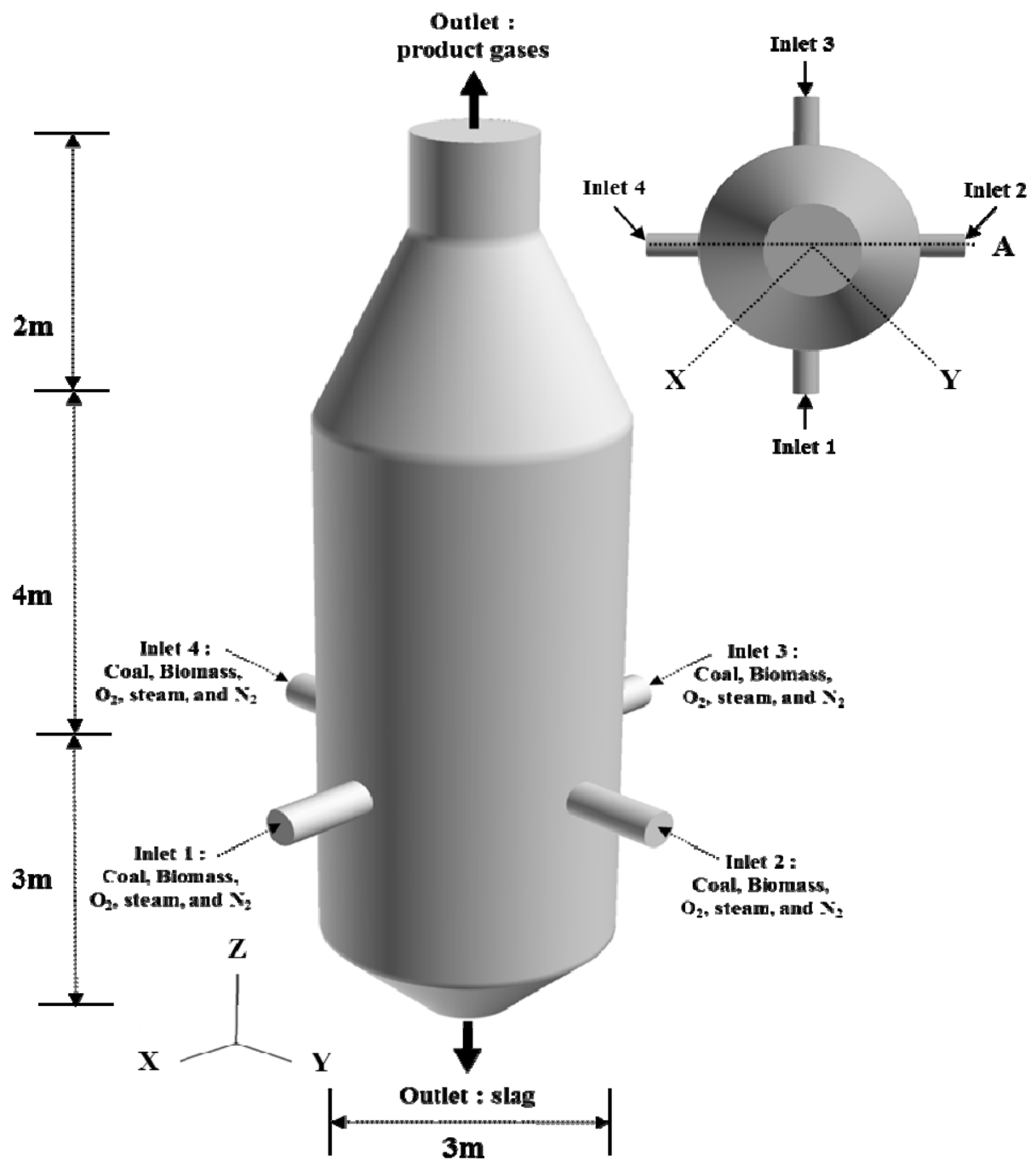

Figure 1. Model gasifier.

Table 1. Properties of Illinois \#6 coal, Drayton coal, and design coal for the SCGP gasifier in Korea.

\begin{tabular}{ccccc}
\hline Analysis & Contents & Illinois \#6 Coal & Drayton Coal & Design Coal \\
\hline & Moisture & 11.12 & 2.0 & 2.06 \\
& Fixed Carbon & 44.19 & 51.25 & 49.25 \\
Proximate analysis (wt\%) & Ash & 9.7 & 12.54 & 9.93 \\
& Volatiles & 34.99 & 34.20 & 38.76 \\
& Total & 100 & 100 & 100 \\
\hline & Moisture & 11.12 & 2.0 & 2.06 \\
& Carbon & 63.75 & 68.01 & 62.36 \\
& Hydrogen & 4.5 & 4.82 & 4.49 \\
& Nitrogen & 1.25 & 1.33 & 0.70 \\
& Chlorine & 0.29 & - & - \\
Ultimate analysis (wt\%) & Sulfur & 2.51 & 0.99 & 0.94 \\
& Ash & 9.7 & 12.54 & 9.93 \\
& Oxygen & 6.88 & 10.39 & 19.53 \\
& Total & 100 & 100 & 100 \\
\hline Calorific value $(\mathrm{HHV})(\mathrm{kcal} / \mathrm{kg})$ & 6481.25 & 6616.03 & 6925.11 \\
\hline
\end{tabular}


The Illinois \#6 coal used in this study contains $11.12 \%$ total moisture on an as-received basis. It was assumed that the coal must be dried to $5 \%$ moisture to allow for smooth flow through the dry feed system [28]. According to Ma and Zitney [27], the minimum, mean, and maximum diameters of Illinois \#6 coal were 74,100, and $297 \mu \mathrm{m}$, respectively.

\section{Numerical Model}

In the numerical procedure, the 3-D, steady-state, Navier-Stokes equations, energy equation, and gas-phase species transport equations were solved in an Eulerian frame of reference. The realized $k-\varepsilon$ model was applied to capture the turbulence flow. The gas-phase species transport equations were solved with the Finite-Rate/Eddy-Dissipation Model. In this model, the Finite-Rate and the Eddy-Dissipation rate were compared, and the slower rate was used to compute the continuous phase reactions. All coal particles were treated as discrete, secondary phase, and dispersed in the continuous phase via the discrete phase model (DPM) with stochastic tracking to consider the turbulent dispersion effect. Coal devolatilization and char gasification were considered. In this model, the particle size did not change while the particle density changed. The particle density was initially $1400 \mathrm{~kg} / \mathrm{m}^{3}$, however, continuously decreased by devolatilization, and further decreased during the char gasification. Two radiation models (discrete ordinate (DO) model and P-1 model) were used for radiation interactions between gas and particle. The domain-based weighted-sum-of-gray-gases model (WSGGM) for the radiative properties of the gases was applied, and the gravitational force was considered in the modeling. Results of the comparison between the two radiation models are presented in Table S1 and Figures S1-S3 of Supplementary Materials, which show a negligible difference between the two models. Coal devolatilization model, gas phase reaction model, and char gasification model were applied as coal reaction sub models in this study.

\subsection{Coal Devolatilization Model}

The generic coal devolatilization reaction by coal pyrolysis can be described as follows [17]:

$$
\text { Coal } \rightarrow \text { volatiles }+\operatorname{char}\left(\mathrm{C}_{(\mathrm{S})} \text { and ash }\right)
$$

The two competing rates model proposed by Kobayashi describes the devolatilization rate as follows [29]:

$$
R_{1}=A_{1} e^{-\left(E_{1} / R T_{p}\right)}, R_{2}=A_{2} e^{-\left(E_{2} / R T_{p}\right)}
$$

where $R_{1}$ and $R_{2}$ are competing rates that control the devolatilization over different temperature ranges. $T_{p}$ is the temperature of the particle $(\mathrm{K}), A_{1}$ and $A_{2}$ are Arrhenius-type pre-exponential factors, $E_{1}$ and $E_{2}$ are activation energies $(\mathrm{J} / \mathrm{kmol})$, and $R$ is the universal gas constant $(8314 \mathrm{~J} / \mathrm{kmol} \cdot \mathrm{K})$. In this study, $A_{1}$ and $A_{2}$ were $2.0 \times 10^{6} \mathrm{~s}^{-1}$ and $1.3 \times 10^{7} \mathrm{~s}^{-1}$, respectively, and $E_{1}$ and $E_{2}$ were $1.046 \times 10^{8} \mathrm{~J} / \mathrm{kmol}$ and $1.674 \times 10^{8} \mathrm{~J} / \mathrm{kmol}$, respectively [29].

The two kinetic rates were weighted to yield an expression for the devolatilization:

$$
\frac{m_{v}(t)}{\left(1-f_{w, o}\right) m_{p, 0}-m_{a}}=\int_{0}^{t}\left(\alpha_{1} R_{1}+\alpha_{2} R_{2}\right) \exp \left(-\int_{0}^{t}\left(R_{1}+R_{2}\right) d t\right) d t
$$


where $m_{v}(t)$ is the devolatilized mass at time $t(\mathrm{~kg}), m_{p, 0}$ is the initial coal particle mass $(\mathrm{kg})$ and $m_{a}$ is the ash content of coal $(\mathrm{kg}) . f_{w, 0}$ is the mass fraction of evaporating/boiling material. In this study, yield factors for $\alpha_{1}$ of design coal, Illinois \#6 coal, and Drayton coal were $\alpha_{1}=0.369, \alpha_{1}=0.371$, and $\alpha_{1}=0.336$, respectively, while those for $\alpha_{2}$ of design coal, Illinois \#6 coal, and Drayton coal were $\alpha_{2}=0.672$ [27].

In this model, volatile matter produced during devolatilization was assumed to be $\mathrm{C}_{\eta} \mathrm{H}_{\theta} \mathrm{O}_{\kappa} . \eta, \theta$, and $\kappa$ can be calculated from the ultimate and proximate analyses of coal. The values of $\eta, \theta$, and $\kappa$ were 1 , 2.761, and 0.264, respectively. Once $\mathrm{CH}_{2.761} \mathrm{O}_{0.264}$ is released, it decomposes into hydro-carbonaceous gas and syngas (i.e., $\mathrm{C}_{x} \mathrm{H}_{y}, \mathrm{CO}$, and $\mathrm{H}_{2}$ ) or is partially oxidized through chemical reactions [30,31]. In this study, $\mathrm{CH}_{4}$, and $\mathrm{C}_{6} \mathrm{H}_{6}$, and $\mathrm{C}_{7} \mathrm{H}_{8}$ were assumed to be the representative species of $\mathrm{C}_{x} \mathrm{H}_{y}$.

\subsection{Gas Phase Reaction Model}

The turbulence-chemistry interaction is modeled through composite Magnussen eddy-dissipation and Arrhenius rates. The constants of Magnussen eddy-dissipation for reactants and products are 4.0 and 0.5 , respectively [29]. The reaction rate for each reaction modeled is defined by taking the smaller of the chemical reaction rate and the turbulent mixing rate [29]. The turbulence mixing rate is a function of turbulence kinetic energy, the dissipation rate of turbulence kinetic energy, and the mole fractions of reactant and product. Turbulence mixing rates can be described as the non-premixed mixing rate and premixed mixing rate. Of these two turbulence mixing rates, the smaller value was used to calculate the reaction rate $\left(R_{r x n, t}\right)$ [29]. The chemical reaction rate $\left(R_{r x n, c}\right)$ can be expressed as:

$$
R_{r \times n, c}=R_{r x n, c}^{\prime} C_{3}^{c}, \quad R_{r x n, c}^{\prime}=A_{r} T^{m} e^{-E_{r} / R T} C_{1}^{a} C_{2}^{b}
$$

where $A_{r}$ is the pre-exponential factor, $T$ is the gas temperature $(\mathrm{K}), m$ is the exponent of temperature. $E_{r}$ is the activation energy $(\mathrm{J} / \mathrm{kmol}), C_{1}$ and $C_{2}$ are the molar concentrations of the first and second reactants, respectively, $a$ and $b$ are the reaction orders corresponding to each reactant, $C_{3}$ is the concentration of a third species that is neither a reactant nor a product, and $c$ is the reaction order corresponding to $C_{3}$. Note that the rates of all reactions except $\mathrm{CO}$ oxidation reaction (Equation (8)) are not related to the concentration of the third species $(c=0)$. For Equation (8), the rate is half order ( $c=0.5)$ with respect to $\mathrm{H}_{2} \mathrm{O}$. The smaller value of the turbulence mixing rate $\left(R_{r x n, t}\right)$ and chemical reaction rate $\left(R_{r x n, c}\right)$ was applied in the CFD calculation and can be expressed as:

$$
R_{r x n}=\min \left(R_{r x n, t}, R_{r x n, c}\right)
$$

Table 2 shows gas phase reactions included in the model and the kinetic parameters of each reaction.

\subsection{Char Gasification Model}

After the complete de-volatilization of volatile matter in the coal particles, heterogeneous reactions between char $\left(\mathrm{C}_{(\mathrm{s})}\right)$ and gas-phase species $\left(\mathrm{O}_{2}, \mathrm{CO}_{2}\right.$, and $\left.\mathrm{H}_{2} \mathrm{O}\right)$ occurred in the gasifier. These heterogeneous reactions have been suggested by Chen et al. [5], Chen et al. [14], Watanabe and Otaka [15], and Luan et al. [18].

The rate of reaction $r(r=1,2,3)$ of the char with gas $n\left(\mathrm{O}_{2}, \mathrm{CO}_{2}\right.$, and $\left.\mathrm{H}_{2} \mathrm{O}\right)$ is described by [29]:

$$
\bar{R}_{\text {char }, r}=A_{p} \eta_{r} R_{\text {char }, r}
$$




$$
R_{\text {char }, r}=R_{k i n, r}\left(p_{n}-\frac{R_{\text {char }}}{D_{0, r}}\right)^{N_{r}}
$$

where $R_{\text {char, } r}$ is the rate of char surface depletion $(\mathrm{kg} / \mathrm{s}), \eta_{r}$ is the effectiveness factor, which was 1.0 for all the reactions in this study, $R_{\text {char }}$ is the rate of char surface reaction per unit area $\left(\mathrm{kg} / \mathrm{m}^{2} / \mathrm{s}\right), N_{r}$ is the mass fraction of surface species $r$ in the particle, $p_{n}$ is the bulk partial pressure of the gas phase $(\mathrm{Pa})$, $D_{0, r}$ is the diffusion rate coefficient for reaction $r\left(\mathrm{~kg} / \mathrm{m}^{2} / \mathrm{s} / \mathrm{Pa}^{0.5}\right), R_{k i n, r}$ is the kinetic rate of reaction $r$ $\left(\mathrm{kg} / \mathrm{m}^{2} / \mathrm{s} / \mathrm{Pa}^{0.5}\right)$, and $N_{r}$ is the reaction order. $D_{0, r}$ is given by:

$$
D_{0, r}=C_{1, r} \frac{\left.\left[\left(T_{p}+T\right) / 2\right)\right]^{0.75}}{d_{p}}
$$

where $T_{P}$ is the particle temperature and $C_{1, r}$ is the molar concentration of the first reactant $\left(\mathrm{O}_{2}\right)$. The kinetic rate of the reaction is defined as:

$$
R_{k i n, r}=A_{r} T_{P}^{\beta_{r}} e^{-\left(E_{r} / R T_{P}\right)}
$$

where $\beta_{r}$ is the exponent of the particle temperature. The kinetic parameters of reactions (25), (26), and

\begin{tabular}{|c|c|c|c|c|c|c|c|}
\hline Gas Phase Reactions & Equation & $A_{r}$ & $E_{r}(\mathrm{~J} / \mathbf{k m o l})$ & $m$ & $a$ & $b$ & Ref. \\
\hline $\mathrm{C}_{\eta} \mathrm{H}_{\theta} \mathrm{O}_{\kappa} \rightarrow \alpha_{c} \mathrm{C}_{7} \mathrm{H}_{8}+\beta_{\mathrm{c}} \mathrm{CO}+\gamma_{\mathrm{c}} \mathrm{H}_{2}$ & (6) & $4.26 \times 10^{6} 1 / \mathrm{s}$ & $1.08 \times 10^{8}$ & 0 & 0 & 0 & [32] \\
\hline $\mathrm{C}_{\eta} \mathrm{H}_{\theta} \mathrm{O}_{\kappa}+\delta_{\mathrm{g}} \mathrm{O}_{2} \rightarrow \varepsilon_{\mathrm{g}} \mathrm{CO}+\zeta_{\mathrm{g}} \mathrm{H}_{2} \mathrm{O}$ & (7) & $9.2 \times 10^{6} 1 / \mathrm{K} / \mathrm{s}$ & $8.02 \times 10^{7}$ & 1 & 0 & 0 & [32] \\
\hline $\mathrm{CO}+0.5 \mathrm{O}_{2} \rightarrow \mathrm{CO}_{2}$ & (8) & $2.239 \times 10^{12}\left(\mathrm{~m}^{3} / \mathrm{kmol}\right)^{0.75} / \mathrm{s}$ & $1.674 \times 10^{8}$ & 0 & 1 & 0.25 & {$[33]$} \\
\hline $\mathrm{H}_{2}+0.5 \mathrm{O}_{2} \rightarrow \mathrm{H}_{2} \mathrm{O}$ & (9) & $6.8 \times 10^{15}\left(\mathrm{~m}^{3} / \mathrm{kmol}\right)^{0.75} / \mathrm{K}^{-1} / \mathrm{s}$ & $1.67 \times 10^{8}$ & -1 & 0.25 & 1.5 & [33] \\
\hline $\mathrm{CH}_{4}+0.5 \mathrm{O}_{2} \rightarrow \mathrm{CO}+2 \mathrm{H}_{2}$ & (10) & $4.4 \times 10^{11}\left(\mathrm{~m}^{3} / \mathrm{kmol}\right)^{0.75} / \mathrm{s}$ & $1.25 \times 10^{8}$ & 0 & 0.5 & 1.25 & [34] \\
\hline $\mathrm{CO}+\mathrm{H}_{2} \mathrm{O} \rightarrow \mathrm{CO}_{2}+\mathrm{H}_{2}$ & (11) & $2.34 \times 10^{10}\left(\mathrm{~m}^{3} / \mathrm{kmol}\right)^{0.5} / \mathrm{s}$ & $2.883 \times 10^{8}$ & 0 & 0.5 & 1 & [35] \\
\hline $\mathrm{H}_{2}+\mathrm{CO}_{2} \rightarrow \mathrm{CO}+\mathrm{H}_{2} \mathrm{O}$ & (12) & $2.2 \times 10^{7}\left(\mathrm{~m}^{3} / \mathrm{kmol}\right)^{0.5} / \mathrm{s}$ & $1.9 \times 10^{8}$ & 0 & 0.5 & 1 & [27] \\
\hline $\mathrm{CH}_{4}+\mathrm{H}_{2} \mathrm{O} \rightarrow \mathrm{CO}+3 \mathrm{H}_{2}$ & (13) & $8.7 \times 10^{7}\left(\mathrm{~m}^{3} / \mathrm{kmol}\right)^{0.5} / \mathrm{s}$ & $2.51 \times 10^{8}$ & 0 & 0.5 & 1 & [27] \\
\hline $\mathrm{CO}+3 \mathrm{H}_{2} \rightarrow \mathrm{CH}_{4}+\mathrm{H}_{2} \mathrm{O}$ & (14) & $5.12 \times 10^{-14} \mathrm{~m}^{3} / \mathrm{kmol} / \mathrm{s}$ & $2.73 \times 10^{4}$ & 0 & 1 & 1 & [9] \\
\hline $\mathrm{C}_{7} \mathrm{H}_{8}+\mathrm{H}_{2} \rightarrow \mathrm{C}_{6} \mathrm{H}_{6}+\mathrm{CH}_{4}$ & (15) & $1.04 \times 10^{12}\left(\mathrm{~m}^{3} / \mathrm{kmol}\right)^{0.5} / \mathrm{s}$ & $2.47 \times 10^{8}$ & 0 & 1 & 0.5 & {$[35]$} \\
\hline $\mathrm{C}_{7} \mathrm{H}_{8}+9 \mathrm{O}_{2} \rightarrow 7 \mathrm{CO}_{2}+4 \mathrm{H}_{2} \mathrm{O}$ & (16) & $1.6 \times 10^{8}\left(\mathrm{~m}^{3} / \mathrm{kmol}\right)^{0.75} / \mathrm{s}$ & $1.255 \times 10^{8}$ & 0 & -0.1 & 1.85 & {$[36]$} \\
\hline $\mathrm{C}_{6} \mathrm{H}_{6}+5 \mathrm{H}_{2} \mathrm{O} \rightarrow 5 \mathrm{CO}+6 \mathrm{H}_{2}+\mathrm{CH}_{4}$ & (17) & $4.4 \times 10^{8} \mathrm{~m}^{3} / \mathrm{kmol} / \mathrm{s}$ & $2.2 \times 10^{8}$ & 0 & 1 & 1 & [37] \\
\hline $\mathrm{C}_{6} \mathrm{H}_{6}+7.5 \mathrm{O}_{2} \rightarrow 6 \mathrm{CO}_{2}+3 \mathrm{H}_{2} \mathrm{O}$ & (18) & $2 \times 10^{8}\left(\mathrm{~m}^{3} / \mathrm{kmol}\right)^{0.75} / \mathrm{s}$ & $1.255 \times 10^{8}$ & 0 & -0.1 & 1.85 & [38] \\
\hline $\mathrm{C}_{6} \mathrm{H}_{6}+3 \mathrm{O}_{2} \rightarrow 6 \mathrm{CO}+3 \mathrm{H}_{2}$ & (19) & $1.58 \times 10^{15} \mathrm{~m}^{3} / \mathrm{kmol} / \mathrm{s}$ & $2.026 \times 10^{8}$ & 0 & 1 & 1 & [39] \\
\hline $\mathrm{H}_{2} \mathrm{O} \rightarrow \mathrm{H}_{2}+0.5 \mathrm{O}_{2}$ & $(20)$ & $2.5 \times 10^{10} \mathrm{~m}^{3} / \mathrm{kmol} / \mathrm{s}$ & $3.5 \times 10^{8}$ & 0 & 1 & 0.5 & [27] \\
\hline
\end{tabular}
(27) are listed in Table 3.

Table 2. Kinetic parameters for gas phase reactions.

Table 3. Kinetic parameters for char gasification (heterogeneous reactions).

\begin{tabular}{ccccccc}
\hline Zone & Global Reactions & Equation & $\boldsymbol{\beta}_{\boldsymbol{r}}$ & $\boldsymbol{A}_{\boldsymbol{r}}\left(\mathbf{k g} / \mathbf{m}^{\mathbf{2}} / \mathbf{s} / \mathbf{P a}^{\mathbf{0 . 5}}\right)$ & $\boldsymbol{E}_{\boldsymbol{r}}(\mathbf{J} / \mathbf{k m o l})$ & $\boldsymbol{R e f}$ \\
\hline \multirow{4}{*}{ Combustion/Gasification } & $\mathrm{C}(\mathrm{s})+0.5 \mathrm{O}_{2} \rightarrow \mathrm{CO}$ & $(25)$ & 0 & 0.052 & $6.1 \times 107$ & {$[14]$} \\
& $\mathrm{C}(\mathrm{s})+\mathrm{CO}_{2} \rightarrow 2 \mathrm{CO}$ & $(26)$ & 0 & 0.0732 & $1.125 \times 108$ & {$[40]$} \\
& $\mathrm{C}(\mathrm{s})+\mathrm{H}_{2} \mathrm{O} \rightarrow \mathrm{CO}+\mathrm{H}_{2}$ & $(27)$ & 0 & 0.0782 & $1.15 \times 108$ & {$[14]$} \\
\hline
\end{tabular}




\section{Numerical Methods}

\subsection{Numerical Scheme}

A commercial CFD code, FLUENT, which employs the finite volume method (FVM), was employed as the solver. The geometry and mesh of the gasifier were generated with a hybrid-mesh using GAMBIT (Version 2.4.6) (see Figure 2). The semi-implicit method for pressure-linked equations (SIMPLE) was used for the pressure-velocity coupling of mass and momentum conservation equations, and a second-order, upwind algorithm was used for discretization. To update the specific heat of the mixture, the mass-weighted mixing law for consistent species was used. The mixture's viscosity, conductivity, and specific heat capacity were assumed to be constants. To effectively control the solution, under-relaxation factors for all variables were less than 0.5 .

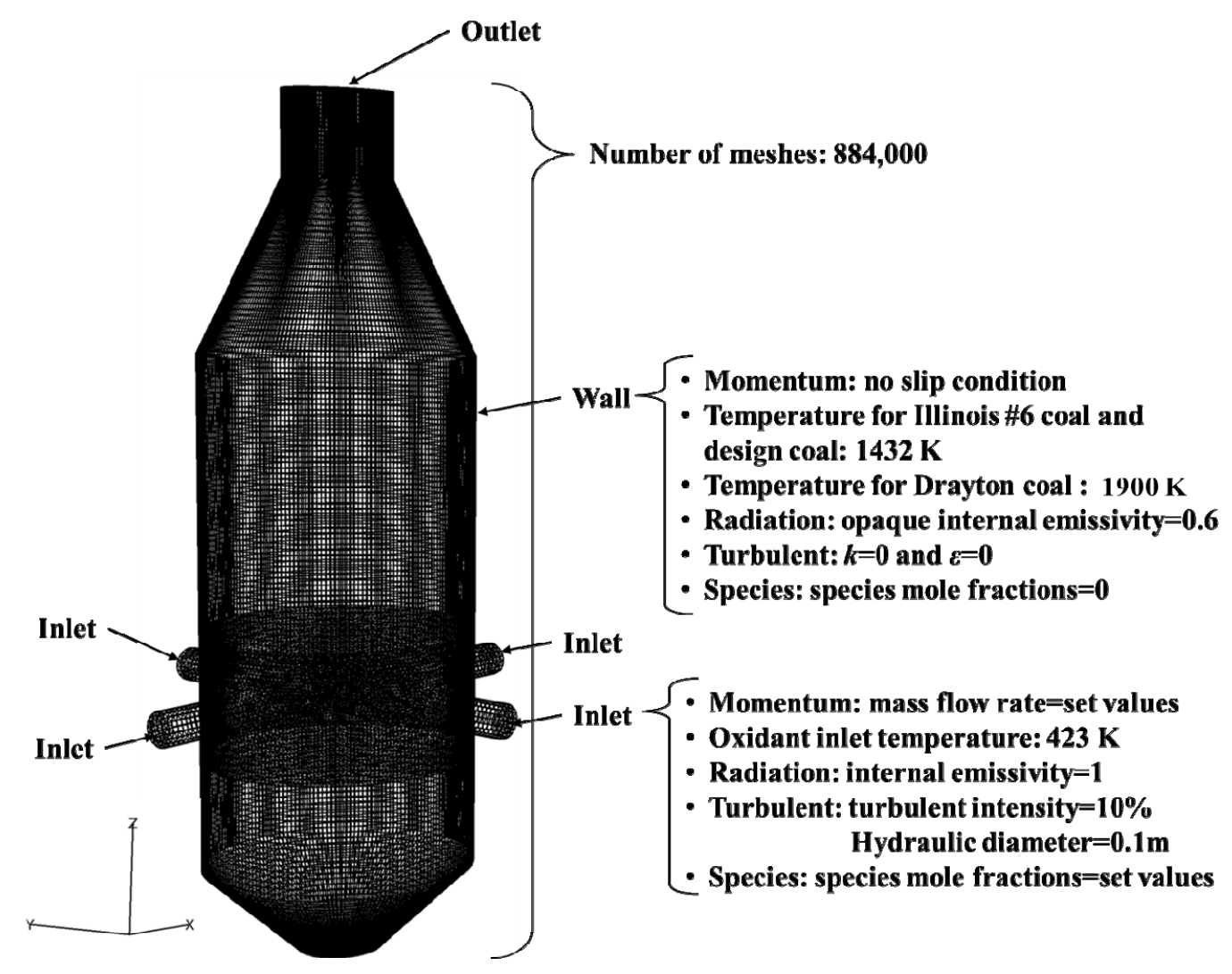

Figure 2. Mesh and boundary conditions.

Calculations were carried out using meshes considering both the 1/4 periodic geometry and whole geometry of the gasifier (See Figure 2). The comparison was made in Figures S4-S9 for spatial distributions of temperature, $\mathrm{H}_{2}$ and $\mathrm{CO}$ molar concentrations (See Supplementary Materials). Considering the time required for calculation, the $1 / 4$ periodic geometry was selected hereafter. The mesh number of 220,000 was determined from a mesh sensitivity study. Sun et al. [17] and Ni et al. [41] also used $1 / 4$ periodic geometry in their numerical simulation of industrial opposed multi-burner (OMB) coal-water slurry entrained flow gasifier. 


\subsection{Numerical Conditions}

\subsubsection{Drayton Coal}

The mixture of $\mathrm{O}_{2}, \mathrm{~N}_{2}$, and steam with coal was injected to the model gasifier. The feed rate, size, and inlet temperature of coal particles were 1889 tons/day, $100 \mu \mathrm{m}$, and $423 \mathrm{~K}$, respectively. The pressure for the model gasifier was 2.6 MPa. These values were obtained from previous literature [42]. In this study, the $\mathrm{O}_{2} /$ coal and steam/coal ratios were 0.88 and 0.07 , respectively [42]. The SCGP coal gasifier should be operated under the ash slagging mode. The wall temperature was assumed to be 1900K, which is higher than the ash fusion temperature of Drayton coal [43]. The internal emissivity of the membrane wall was assumed to be 0.6 [27]. The mesh and boundary conditions for numerical analysis are summarized in Figure 2.

\subsubsection{Illinois \#6 Coal and Design Coal}

For Illinois \#6 coal, two feeding rates of 2450 tons/day and 1923 tons/day were used. The inlet temperature of coal particles was $423 \mathrm{~K}$. For design coal, the feeding rate and inlet temperature of coal particles were 2450 tons/day and $423 \mathrm{~K}$, respectively. For both coals, the pressure for the model gasifier was 4.2 $\mathrm{MPa}$. These values were suggested by Doosan Heavy Industries \& Construction Company [9]. In this study, the $\mathrm{O}_{2} /$ coal and steam/coal ratios were $0.1-1.1$ and $0.05-0.2$, respectively. The $\mathrm{N}_{2} /$ coal ratio was 0.112 [9]. The wall temperature was assumed to be $1432 \mathrm{~K}$, which is higher than the ash fusion temperature of Illinois \#6 coal [44]. The internal emissivity of the membrane wall was assumed to be 0.6 [27].

\section{Results and Discussion}

Three parameters are typically chosen in order to evaluate the performance of a gasifier [45]: Average temperature at the cross-section of the gasifier exit, cold gas efficiency (CGE), and carbon conversion efficiency (CCE). The CGE represents how the higher heating value (HHV) of solid fuel converts to the HHV of gas fuels. The CGE is defined as:

$$
\mathrm{CGE}=\frac{\text { HHV of product gas }}{\text { HHV of feedstock }}
$$

The CCE represents the conversion ratio of carbon in the gas fuels relative to the total carbon in the solid fuel and is defined as:

$$
\mathrm{CCE}=1-\frac{\text { mass of carbon particles in outlet }}{\text { mass of carbon particles in feedstock }}
$$

In addition to these three parameters, mole fractions of product gases at the exit were selected in order to evaluate and verify the performance of the SCGP gasifier.

In order to investigate effects of coal size distribution on temperature and mole fractions of product gases at the gasifier exit, calculations were carried out by assuming that the size distribution of Illinois \#6 coal follows the Rosin-Rammler distribution. In addition, calculations were performed by assuming that the coal size was uniform as $100 \mu \mathrm{m}$. Table 4 shows that these two calculated results are 
slight different with each other. Therefore, in the following, it was assumed that the coal size was uniform as $100 \mu \mathrm{m}$.

Table 4. Effect of coal size distribution on temperature and mole fractions of product gases at the gasifier exit (Feeding rate of coal $=28.35 \mathrm{~kg} / \mathrm{s}$ ).

\begin{tabular}{ccc}
\hline Contents & $\begin{array}{c}\text { Specific Coal Particle Size } \\
(\mathbf{1 0 0} \boldsymbol{\mu m})\end{array}$ & $\begin{array}{c}\text { Coal Particle Size Distributions } \\
\mathbf{( 7 4 - 2 9 7} \boldsymbol{\mu m})\end{array}$ \\
\hline Mole Fraction of $\mathrm{CO}$ & 0.5702 & 0.5689 \\
Mole Fraction of $\mathrm{H}_{2}$ & 0.2967 & 0.2755 \\
Mole Fraction of $\mathrm{CO}_{2}$ & 0.0188 & 0.0315 \\
Mole Fraction of $\mathrm{CH}_{4}$ & 0.00076 & 0.00095 \\
Mole Fraction of $\mathrm{H}_{2} \mathrm{O}$ & 0.0375 & 0.0581 \\
Mole Fraction of $\mathrm{N}_{2}$ & 0.0213 & 0.0329 \\
Exit Temperature $(\mathrm{K})$ & 1847 & 1874 \\
\hline
\end{tabular}

\subsection{Verification of Simulation}

\subsubsection{Drayton Coal}

In this CFD analysis, the gas-phase species transport equations were solved via the Finite-Rate/Eddy-Dissipation Model. In order to compare and verify actual operating data from Demkolec demo IGCC facility in Netherlands with CFD results, the CFD calculation were performed for the selected $\mathrm{O}_{2} /$ coal and steam/coal ratios (0.88 and 0.07 , respectively) [42]. The DO radiation model was used. The product gases ( $\mathrm{CO}, \mathrm{H}_{2}, \mathrm{CO}_{2}, \mathrm{~N}_{2}$, others), $\mathrm{CGE}, \mathrm{CCE}$ and temperature at the exit were calculated. Table 5 shows that the CFD analysis results (for $1 / 4$ periodic geometry) were in good agreement with the actual operating data from Demkolec demo IGCC facility. The CFD analysis results for the whole geometry are presented in Supplementary Materials.

Table 5. Comparison of the CFD results with actual operating data from Demkolec demo IGCC facility.

\begin{tabular}{ccc}
\hline Contents & Demkolec Plant (SCGP Gasifier) [42] & CFD Calculation Results \\
\hline $\mathrm{CO}(\%)$ & 63.4 & $62.96(34.19 \mathrm{~kg} / \mathrm{s})$ \\
$\mathrm{H}_{2}(\%)$ & 28.4 & $29.23(1.10 \mathrm{~kg} / \mathrm{s})$ \\
$\mathrm{CO}_{2}(\%)$ & 1.5 & $2.62(2.23 \mathrm{~kg} / \mathrm{s})$ \\
$\mathrm{N}_{2}(\%)$ & 6.2 & $4.35(1.13 \mathrm{~kg} / \mathrm{s})$ \\
Others (\%) & 0.5 & $1.84(1.72 \mathrm{~kg} / \mathrm{s})$ \\
Temperature (K) & & 2068.65 \\
CGE (\%) & 78.6 & 78.29 \\
$\mathrm{CCE}(\%)$ & $98-99.5$ & 99.63 \\
\hline
\end{tabular}

Feed rate of coal: $21.86 \mathrm{~kg} / \mathrm{s}$

Operating conditions

$\mathrm{O}_{2} /$ coal ratio: 0.885

Steam/coal ratio: 0.071

$\mathrm{N}_{2} /$ coal ration: 0.044 


\subsubsection{Illinois \#6 Coal}

For the selected $\mathrm{O}_{2} /$ coal, steam/coal, and $\mathrm{N}_{2} /$ coal ratios $(0.798,0.103$, and 0.112 , respectively) [28], the flow velocity vectors, particle trajectories, and particle residence times are shown in Figure 3. The DO radiation model was also used. Both gas and particle motions had axisymmetric behaviors. As a stream of coal particles and gases was injected through an inlet, it met another stream injected from the opposite inlet, and some coal particles and gases headed toward the gasifier exit while the others followed downward recirculation flows. This recirculation motion in the lower part of the gasifier led to the longest particle residence time, which was $11.18 \mathrm{~s}$. The average values of particle residence time (the time elapsed for one particle to exit the gasifier once the particle enters the gasifier) were about 3-6 s.

Spatial distributions of temperature, $\mathrm{CO}$ molar concentration, and $\mathrm{H}_{2}$ molar concentration in the gasifier are shown in Figure 4. In Figure 4a, temperatures were relatively high in Region A due to the combustion of coal with injected oxygen, while the temperature decreased in Region $\mathrm{B}$ due to gasification reactions of char with $\mathrm{O}_{2}, \mathrm{H}_{2} \mathrm{O}$, and $\mathrm{CO}_{2}$ under the oxidant-starved condition. The temperature was also low in Region $\mathrm{C}$ due to devolatilization of coal. Figure $4 \mathrm{~b}$ shows that the $\mathrm{CO}$ molar concentration was therefore lower in Region 1 than in Regions 2 and 3. In Figure 4c, the molar concentration of $\mathrm{H}_{2}$ in Region II was lower than in Regions I and III. The different $\mathrm{H}_{2}$ concentrations among regions can also be explained by temperature differences in those regions.

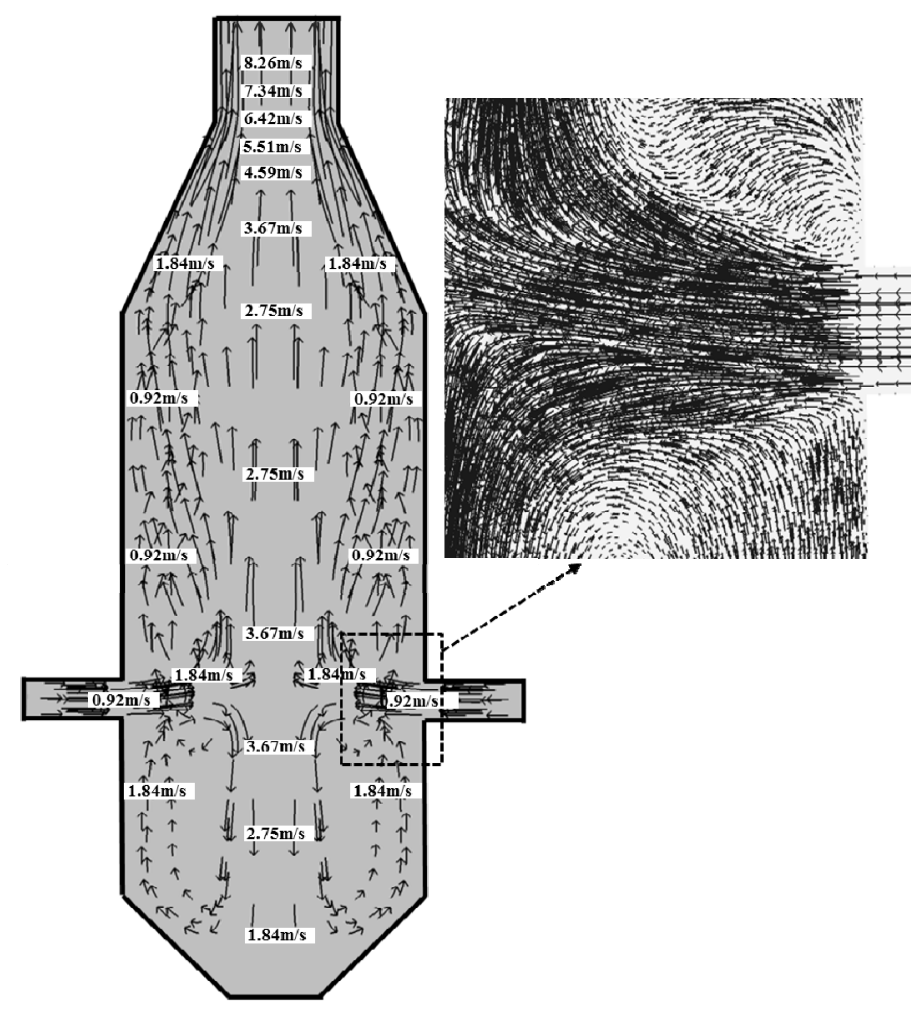

(a)



(b)

Figure 3. Distributions of flow velocity and particle residence time ( $Z-A$ plane, see Figure 1). (a) Flow velocity vector $(\mathrm{m} / \mathrm{s})$; (b) Particle trajectories and residence time. 


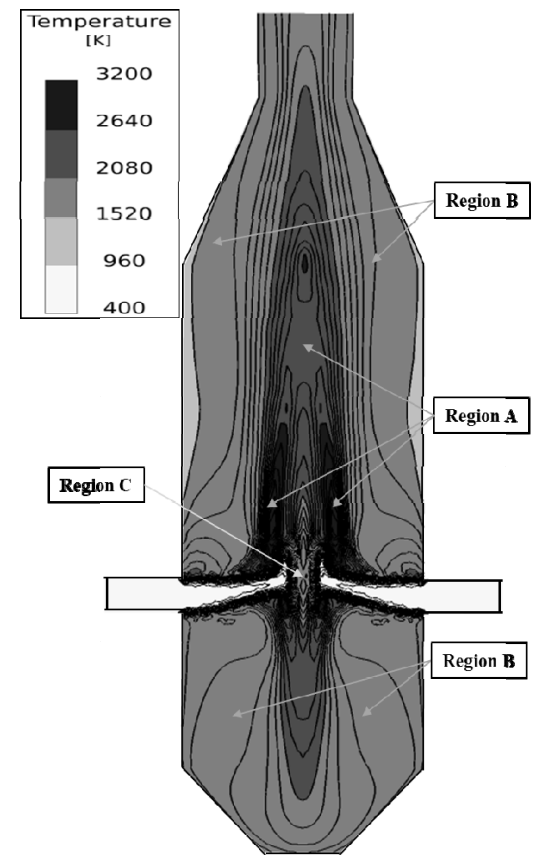

(a)

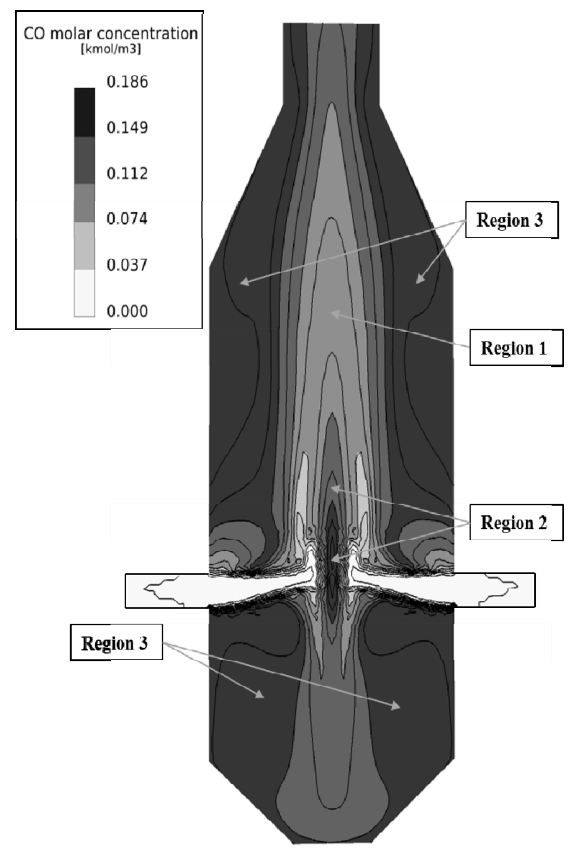

(b)



(c)

Figure 4. Distributions of temperature, $\mathrm{CO}$, and $\mathrm{H}_{2}$ molar concentrations. (a) Temperature; (b) Molar concentration of CO; (c) Molar concentration of $\mathrm{H}_{2}$.

Finally, the CFD analysis results were compared with two different ASPEN Plus results introduced in a report of NETL, where Illinois \#6 coal was used [28]. The mole fractions of product gases at the gasifier exit were calculated, as were the CCE and exit temperature. Table 6 shows that the CFD analysis results were in good agreement with ASPEN Plus calculation results.

Table 6. Comparison of the CFD results with ASPEN Plus results of NETL report.

\begin{tabular}{|c|c|c|c|c|c|c|}
\hline Contents & $\begin{array}{c}\text { Our CFD } \\
\text { Results }\end{array}$ & $\begin{array}{l}\text { Our ASPEN } \\
\text { Plus Results }\end{array}$ & $\begin{array}{c}\text { ASPEN Plus } \\
\text { Results of } \\
\text { NETL [28] }\end{array}$ & $\begin{array}{c}\text { Our CFD } \\
\text { Results }\end{array}$ & $\begin{array}{l}\text { Our ASPEN } \\
\text { Plus Results }\end{array}$ & $\begin{array}{c}\text { ASPEN Plus } \\
\text { Results of } \\
\text { NETL [28] }\end{array}$ \\
\hline Mole Fraction of CO & 0.5702 & 0.5421 & 0.5797 & 0.5016 & 0.4907 & 0.5187 \\
\hline Mole Fraction of $\mathrm{H}_{2}$ & 0.2967 & 0.3171 & 0.3006 & 0.2814 & 0.2981 & 0.2691 \\
\hline Mole Fraction of $\mathrm{CO}_{2}$ & 0.0188 & 0.0238 & 0.0143 & 0.0412 & 0.0514 & 0.0126 \\
\hline Mole Fraction of $\mathrm{CH}_{4}$ & 0.00076 & 0.00031 & 0.0006 & 0.00023 & 0.00017 & 0.0005 \\
\hline Mole Fraction of $\mathrm{H}_{2} \mathrm{O}$ & 0.0375 & 0.0107 & 0.0252 & 0.0985 & 0.1153 & 0.1278 \\
\hline Mole Fraction of $\mathrm{N}_{2}$ & 0.0213 & 0.0159 & 0.0567 & 0.0312 & 0.0135 & 0.0507 \\
\hline Others & 0.05474 & 0.09009 & 0.0229 & 0.04587 & 0.03083 & 0.0206 \\
\hline Exit Temperature (K) & 1846.55 & $\begin{array}{c}1850 \\
\text { (Calculation } \\
\text { temperature) }\end{array}$ & 1850.15 & 1887.42 & $\begin{array}{c}1895 \\
\text { (Calculation } \\
\text { temperature) }\end{array}$ & 1895.15 \\
\hline CCE $(\%)$ & 99.3 & - & 99.5 & 99.7 & - & 99.8 \\
\hline CGE (\%) & 78.7 & - & 79.5 & 77.1 & - & 78.1 \\
\hline \multirow{4}{*}{ Operating conditions } & \multicolumn{3}{|c|}{ Feed rate of coal: $28.35 \mathrm{~kg} / \mathrm{s}$} & \multicolumn{3}{|c|}{ Feed rate of coal: $22.26 \mathrm{~kg} / \mathrm{s}$} \\
\hline & \multicolumn{3}{|c|}{ O2/coal ratio: 0.798} & \multicolumn{3}{|c|}{ O2/coal ratio: 0.881} \\
\hline & \multicolumn{3}{|c|}{ Steam/coal ratio: 0.103} & \multicolumn{3}{|c|}{ Steam/coal ratio: 0.127} \\
\hline & \multicolumn{3}{|c|}{$\mathrm{N} 2 /$ coal ration: 0.112} & \multicolumn{3}{|c|}{$\mathrm{N} 2 /$ coal ration: 0.165} \\
\hline Coal & \multicolumn{6}{|c|}{ Illinois \#6 coal } \\
\hline
\end{tabular}


To understand the effect of gas-phase chemical reactions on the CFD results, additional calculations were conducted using the Eddy-Dissipation Model. Figure 5 shows that the effect of gas-phase chemical reactions on the mole fractions of $\mathrm{CO}, \mathrm{H}_{2}, \mathrm{CO}_{2}$, and $\mathrm{H}_{2} \mathrm{O}$ at the gasifier exit was negligible. This negligible effect can be explained with the Damköhler number (Da). When chemical reaction rates are fast in comparison with fluid mixing rates (convective mass transport regime), Da is greater than unity. Conversely, when the reaction rates are slow in comparison with mixing rates (reaction rate regime), $\mathrm{Da}$ is lower than unity. The CFD analysis showed that the average temperature in the gasifier was $1855 \mathrm{~K}$, leading to $\mathrm{Da}>1$. Consequentially, the turbulent mixing rate was more dominant than the chemical reaction rate in the CFD analysis.

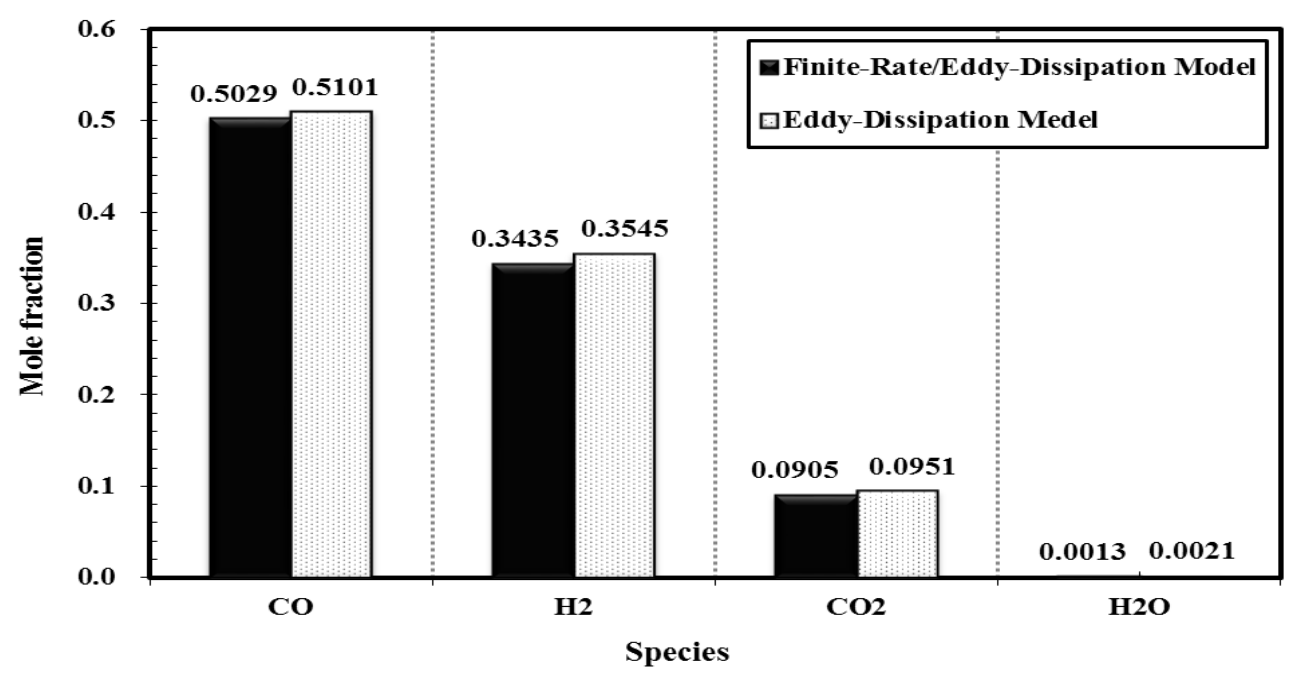

Figure 5. Effect of gas-phase chemical reactions on product yields.

\subsubsection{Design Coal}

For the SCGP gasifier in Korea, kinetic-based calculation was carried out by using ASPEN Plus and CFD analysis by using ANSYS FLUENT. The DO radiation model was used. $\mathrm{The}_{2} /$ coal ratio varied between 0.1 and 1.1, while the steam/coal and $\mathrm{N}_{2} /$ coal ratios were 0.05 and 0.112 , respectively. The amounts of $\mathrm{O}_{2}$ and $\mathrm{N}_{2}$ varied since the amount of coal was fixed in this study. The mole fractions of $\mathrm{CO}, \mathrm{CO}_{2}, \mathrm{H}_{2}$, and $\mathrm{H}_{2} \mathrm{O}$ determined from both $\mathrm{CFD}$ analysis and kinetic-based calculation are shown in Figure 6. In the kinetic-based calculation, reaction temperatures were assumed to be 1200-2611 K, which were obtained from the CFD analysis of exit temperatures for $\mathrm{O}_{2} /$ coal ratios of $0.1-1.1$, respectively. The kinetic-based calculation results using APSEN Plus were in good agreement with those of the CFD analysis.

In Figure 6a, $\mathrm{H}_{2}$ mole fractions determined from both the kinetic-based calculation and CFD analysis decreased with increasing the $\mathrm{O}_{2} /$ coal ratio from 0.1 to 0.5 , while they did not change for $\mathrm{O}_{2} /$ coal ratios higher than 0.5 . In Figure $6 \mathrm{~b}, \mathrm{H}_{2} \mathrm{O}$ mole fractions for the kinetic-based calculation and CFD analysis were nearly zero ( 0.001 or so). The reason was that the injected amount of $\mathrm{H}_{2} \mathrm{O}$ used for the case of design coal was lower (steam/coal ratio: 0.05 ) than that used for the case of Illinois \#6 coal (steam/coal ratio: 0.103). In the simulation, the following reactions were considered; $\mathrm{CO}+\mathrm{H}_{2} \mathrm{O} \rightarrow \mathrm{CO}_{2}+\mathrm{H}_{2}$, $\mathrm{CH}_{4}+\mathrm{H}_{2} \mathrm{O} \rightarrow \mathrm{CO}+3 \mathrm{H}_{2}, \mathrm{C}_{6} \mathrm{H}_{6}+5 \mathrm{H}_{2} \mathrm{O} \rightarrow 5 \mathrm{CO}+6 \mathrm{H}_{2}+\mathrm{CH}_{4}$, as well as $\mathrm{C}_{(\mathrm{s})}+\mathrm{H}_{2} \mathrm{O} \rightarrow \mathrm{CO}+\mathrm{H}_{2}$. Therefore, the injected $\mathrm{H}_{2} \mathrm{O}$ was exhausted and thus the remaining $\mathrm{H}_{2} \mathrm{O}$ mole fraction was nearly zero. 
Both the CFD analysis and kinetic-based calculation show that for $\mathrm{O}_{2} /$ coal ratios of $0.1-0.5$, the reaction of $\mathrm{C}_{(\mathrm{s})}+0.5 \mathrm{O}_{2} \rightarrow \mathrm{CO}$ mainly occurred because of insufficient $\mathrm{O}_{2}$, resulting in an increasing $\mathrm{CO}$ mole fraction with the $\mathrm{O}_{2} /$ coal ratio. For $\mathrm{O}_{2} /$ coal ratios higher than 0.5 , however, the $\mathrm{CO}$ mole fraction decreased while the $\mathrm{CO}_{2}$ mole fraction increased (see Figure 6c,d) because the reaction of $\mathrm{C}_{(\mathrm{s})}+\mathrm{O}_{2} \rightarrow \mathrm{CO}_{2}$ occurred with increasing $\mathrm{O}_{2}$.

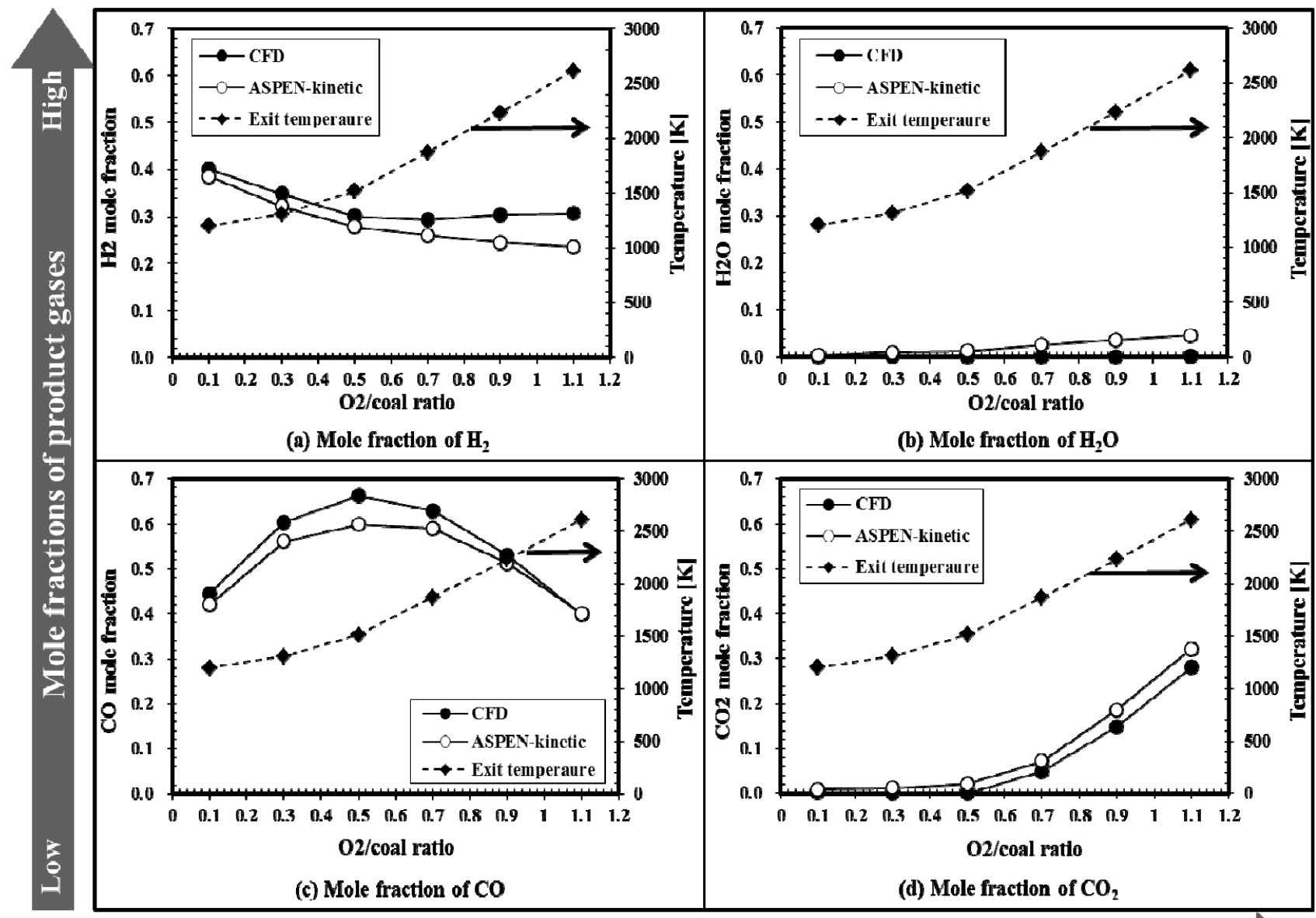

Figure 6. Comparison between CFD and ASPEN Plus results.

\subsection{Effects of O2/Coal and Steam/Coal Ratios (Design Coal)}

In the previous sections, the CFD analysis was validated with plant operating data (using Drayton coal) and a kinetic-based calculation (using Illinois \#6 coal and design coal). In this section, a parametric study was carried out using design coal for the SCGP gasifier in Korea with various $\mathrm{O}_{2} /$ coal ratios and steam/coal ratios and the results are discussed.

Figure 7 shows that the exit temperature of the gasifier increased with increasing $\mathrm{O}_{2} /$ coal ratio since the increasing $\mathrm{O}_{2}$ increased the exothermic reaction. Elliott et al. reported that ash, which remains when coal is gasified via the IGCC process, can melt at 1673-1773 K [46]. Therefore, the exit temperature of a gasifier should be maintained at a temperature higher than $\sim 1800 \mathrm{~K}$. The exit temperature gradually decreased with increasing steam/coal ratio since the endothermic carbon-steam gasification reaction took place. This is confirmed by the fact that at high $\mathrm{O}_{2} /$ coal, where 
hydrogasification plays a minor role, the temperature change decreased till collapsing at the same value for $\mathrm{O}_{2} / \mathrm{coal}>1.1$.

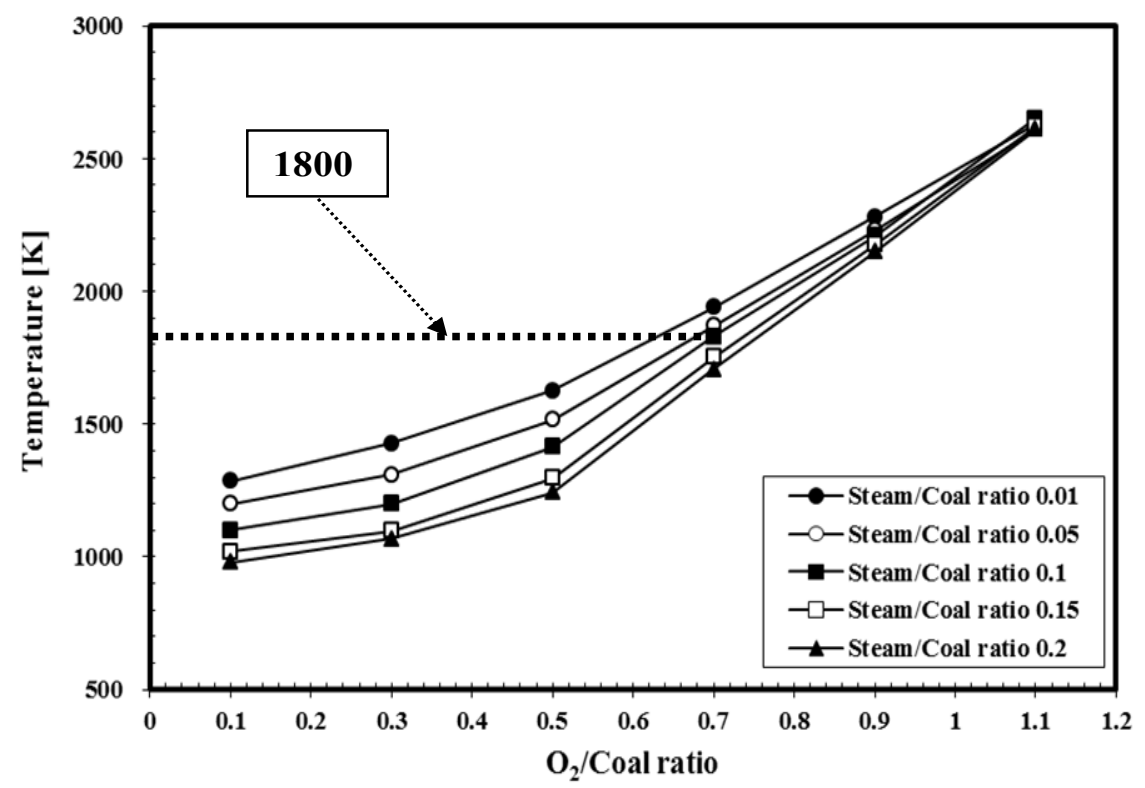

Figure 7. Temperature at outlet with respect to $\mathrm{O} 2 /$ coal and steam/coal ratios.

Mole fractions of $\mathrm{CO}, \mathrm{CO}_{2}$, and $\mathrm{H}_{2}$ with different $\mathrm{O}_{2} /$ coal and steam/coal ratios are shown in Figure 8 . For $\mathrm{O}_{2} /$ coal ratios of $0.1-0.5$, the reactions of $\mathrm{C}_{(\mathrm{s})}+0.5 \mathrm{O}_{2} \rightarrow \mathrm{CO}$ (oxygen gasification), $\mathrm{C}_{(\mathrm{s})}+\mathrm{CO}_{2} \rightarrow 2 \mathrm{CO}$ (Bouduard reaction), and $\mathrm{C}_{(\mathrm{s})}+\mathrm{H}_{2} \mathrm{O} \rightarrow \mathrm{CO}+\mathrm{H}_{2}$ (hydrogasification) occurred owing to insufficient $\mathrm{O}_{2}$, resulting in an increasing $\mathrm{CO}$ mole fraction with the increasing $\mathrm{O}_{2} /$ coal ratio. For $\mathrm{O}_{2} /$ coal ratios higher than 0.5, however, the $\mathrm{CO}$ mole fraction decreased while the $\mathrm{CO}_{2}$ mole fraction increased (see Figure 8a,b) due to the reaction of $\mathrm{C}_{(\mathrm{s})}+\mathrm{O}_{2} \rightarrow \mathrm{CO}_{2}$ with increasing $\mathrm{O}_{2}$. In Figure 8c, the $\mathrm{H}_{2}$ mole fraction decreased with increasing $\mathrm{O}_{2}$ /coal ratio $0.1-0.5$ by reaction of $\mathrm{H}_{2}+0.5 \mathrm{O}_{2} \rightarrow \mathrm{H}_{2} \mathrm{O}$, and then that gradually increased with $\mathrm{O}_{2} /$ coal ratios higher than 0.5 by reactions of $\mathrm{CO}+\mathrm{H}_{2} \mathrm{O} \rightarrow \mathrm{CO}_{2}+\mathrm{H}_{2}$ and $\mathrm{C}_{(\mathrm{s})}+\mathrm{H}_{2} \mathrm{O} \rightarrow \mathrm{CO}+\mathrm{H}_{2}$. In Figure $8 \mathrm{~d}$, the $\mathrm{H}_{2} \mathrm{O}$ mole fraction did not change for increasing $\mathrm{O}_{2} /$ coal ratios. The $\mathrm{CO}$ mole fraction gradually decreased with increasing steam/coal ratio, while $\mathrm{H}_{2}$ and $\mathrm{CO}_{2}$ mole fractions gradually increased with increasing steam/coal ratio. This phenomenon can be explained by the forward water gas shift reaction $\left(\mathrm{CO}+\mathrm{H}_{2} \mathrm{O} \rightarrow \mathrm{H}_{2}+\mathrm{CO}_{2}\right)$. The $\mathrm{H}_{2} \mathrm{O}$ mole fraction increased with increasing steam/coal ratio due to increasing amount of steam.

The effects of $\mathrm{O}_{2} /$ coal and steam/coal ratios on CCE and CGE are shown in Figure 9. The CCE increased with increasing $\mathrm{O}_{2} /$ coal ratio $0.1-0.7$ and reached $99.0 \%$ at $\mathrm{O}_{2} /$ coal ratios higher than 0.7 (see Figure 9a). On the other hand, the CGE increased with increasing $\mathrm{O}_{2} /$ coal ratio $0.1-0.7$, but decreased at $\mathrm{O}_{2} /$ coal ratios higher than 0.7. This $\mathrm{CGE}$ result can be explained by the $\mathrm{CO}$ and $\mathrm{CO}_{2}$ mole fractions in Figure 8a,b. CCE did not change much with increasing steam/coal ratios while CGE gradually increased with increasing steam/coal ratio due to gradual increase in $\mathrm{H}_{2}$ mole fraction caused by water gas shift reaction as well as steam gasification reaction of char $\left(\mathrm{C}_{(\mathrm{s})}+\mathrm{H}_{2} \mathrm{O} \rightarrow \mathrm{CO}+\mathrm{H}_{2}\right)$. Considering temperature and CGE at gasifier exit, the optimal steam/coal ration in the SCGP gasifier in Korea is considered as 0.05 for $\mathrm{O}_{2} /$ coal ratio 0.7. 


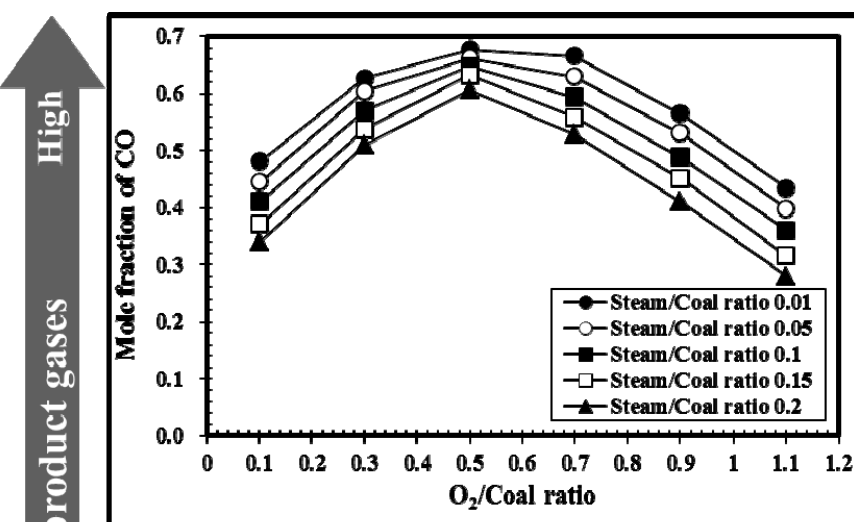

(a) Mole fraction of $\mathrm{CO}$

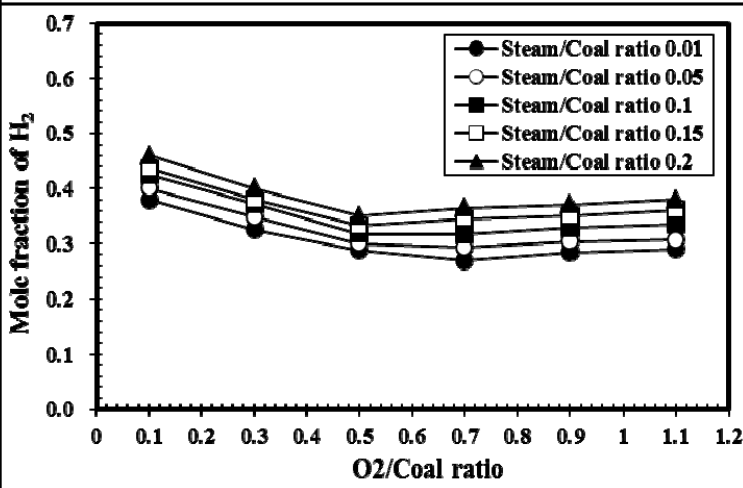

(c) Mole fraction of $\mathrm{H}_{2}$

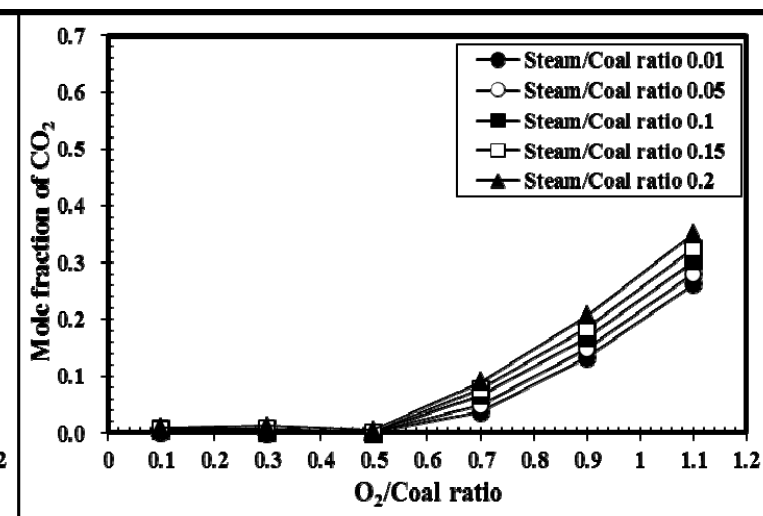

(b) Mole fraction of $\mathrm{CO}_{2}$



High

Figure 8. Mole fractions of $\mathrm{CO}, \mathrm{CO}_{2}, \mathrm{H}_{2}$, and $\mathrm{H}_{2} \mathrm{O}$ with the $\mathrm{O}_{2} /$ coal and steam/coal ratios.

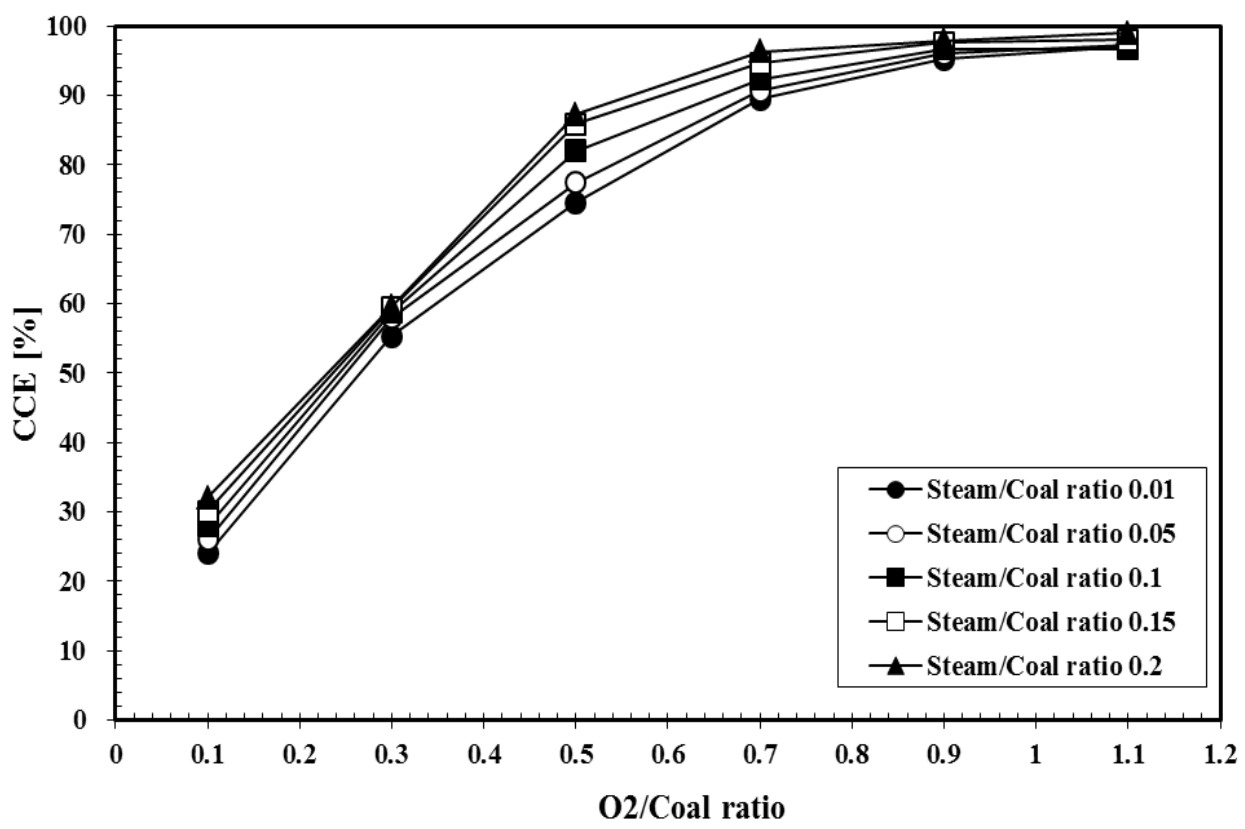

(a)

Figure 9. Cont. 




(b)

Figure 9. Efficiencies at outlet with respect to the $\mathrm{O}_{2} /$ coal and steam/coal ratios. (a) Carbon conversion efficiency (CCE); (b) Cold gas efficiency (CGE).

Water tube membrane is used as the outside wall of the SCGP gasifier. Hence, the heat flux at the wall is an important parameter to determine stable operation of the SCGP gasifier. The effects of $\mathrm{O}_{2} /$ coal and steam/coal ratios on wall heat flux are shown in Figure 10. The wall heat flux increased with increasing $\mathrm{O}_{2} /$ coal ratio due to exothermic reaction with increasing $\mathrm{O}_{2}$ amount, while decreased with increasing steam/coal ratio due to cooling effect by injecting additional steam at a temperature of $423 \mathrm{~K}$. Low or negative wall heat flux values for low $\mathrm{O}_{2} /$ coal ratios imply endothermic reaction by insufficient $\mathrm{O}_{2}$ supply.



Figure 10. Wall heat flux of gasifier. 


\section{Conclusions}

This paper disclosed, for the first time, three-dimensional CFD modeling results of gasification performance in a one-stage entrained-bed coal gasifier (SCGP gasifier), after careful verification and comparison with actual plant operating data and ASPEN Plus calculations, respectively. After the validation, design coal for the SCGP gasifier in Korea was used for parametric study with various $\mathrm{O}_{2} /$ coal and steam/coal ratios. Carbon conversion efficiency, cold gas efficiency, temperature, and species mole fractions at the gasifier exit were calculated, as were spatial distributions of temperature and species concentrations. Optimal $\mathrm{O}_{2} / \mathrm{coal}$ and steam/coal ratios for the SCGP gasifier using design coal were found to be 0.7 and 0.05 , respectively, for the selected operating conditions.

\section{Supplementary Materials}

Supplementary materials can be accessed at: http://www.mdpi.com/1996-1073/8/5/4216/s1.

\section{Acknowledgments}

This work was supported by a grant from the Converged Energy Materials Research Center (CEMRC), funded by the Agency for Defense Development (NE-31).

\section{Author Contributions}

Sang Shin Park performed 3-D modeling for parametric study and Aspen Plus calculation; Hyo Jae Jeong advised and recommended appropriate model for 3-D modeling; Jungho Hwang conceived the project and obtained the financial support; Sang Shin Park and Jungho Hwang wrote the paper.

\section{Conflicts of Interest}

The authors declare no conflict of interest.

\section{References}

1. Yun, Y.S.; You, Y.D.; Chung, S.W. Selection of IGCC candidate coals by pilot scale gasifier. Fuel Process. Technol. 2007, 88, 107-116.

2. Shinada, O.; Yamada, A.; Koyama, Y. The development of advanced energy technologies in Japan IGCC: A key technology for the 21st century. Energy Convers. Manag. 2002, 43, 1221-1233.

3. Necille, A.; Holt, H. Operating experience and improvement opportunities for coal-based IGCC plants. Mater. High Temp. 2003, 20, 112-122.

4. Liebner, W.; Hauser, N. Optimizing costing study for a 500 MW IGCC power plant based on Shell Gasification Gasification Process. In Proceedings of the Electric Power Research Institute (EPRI) Gasification Conference, San Francisco, CA, USA, 2-4 October 1996.

5. Chen, C.J.; Hung, C.I.; Chen, W.H. Numerical investigation on performance of coal gasification under various. Appl. Energy 2012, 100, 218-228.

6. Zhang, G.; Yang, Y.; Jin, H.; Xu, G.; Zhang, K. Proposed combined-cycle power system based on oxygen-blown coal partial gasification. Appl. Energy 2012, 102, 735-745. 
7. HM Associate Inc.; Princeton Energy Resources International LLC.; TFB Consulting. Assessment of the Commercial Potential for Small Gasification Combined Cycle and Fuel Cell Systems Phase II Final Draft Report; U.S. Department of Energy Office of Fossil Energy Office of Coal and Power Systems: Washington, DC, USA, 2003.

8. U.S. Government Printing Office. Gasification Markets and Technologies-Present and Future: An Industry Perspective; U.S. Government Printing Office: Washington, DC, USA, 2002.

9. Lee, H.; Choi, S.; Paek, M. A simple process modelling for a dry-feeding entrained bed coal gasifier. Proc. Inst. Mech. Eng. A J. Power Energy 2011, 225, 74-84.

10. Lee, H.H.; Lee, J.C.; Joo, Y.J.; Oh, M.; Lee, C.H. Dynamic modeling of Shell entrained flow gasifier in an integrated gasification combined cycle process. Appl. Energy 2014, 131, 425-440.

11. Gazzani, M.; Manzolini, G.; Macchi, E.; Ghoniem, A.F. Reduced order modeling of the Shell-Prenflo entrained flow gasifier. Fuel 2013, 104, 822-837.

12. Monaghan, R.F.D.; Ghoniem, A.F. A dynamic reduced order model for simulating entrained flow gasifiers. Part II: Model validation and sensitivity analysis. Fuel 2012, 94, 280-297.

13. Monaghan, R.F.D.; Ghoniem, A.F. A dynamic reduced order model for simulating entrained flow gasifiers. Part I: Model development and description. Fuel 2012, 91, 61-80.

14. Chen, C.X.; Horio, M.; Kojima, T. Numerical simulation of entrained flow coal gasifiers. Part I: Modeling of coal gasification in an entrained flow gasifier. Chem. Eng. Sci. 2000, 55, 3861-3874.

15. Watanabe, H.; Otaka, M. Numerical simulation of coal gasification in entrained flow coal gasifier. Fuel 2006, 85, 1935-1943.

16. Slezak, A.; Kuhlman, J.M.; Shadle, L.J.; Spenik, J.; Shi, S. CFD simulation of entrained-flow coal gasification: Coal particle density/size fraction effects. Powder Technol. 2010, 203, 98-108.

17. Sun, Z.; Dai, Z.; Zhou, Z.; Guo, Q.; Yu, G. Numerical simulation of industrial opposed multi-burner coal-water slurry entrained flow gasifier. Ind. Eng. Chem. Res. 2012, 51, 2560-2569.

18. Luan, Y.T.; Chyou, Y.P.; Wang, T. Numerical analysis of gasification performance via finite-rate model in a cross-type two-stage gasifier. Int. J. Heat Mass Transf. 2013, 57, 558-566.

19. Kumar, M.; Ghoniem, A.F. Multiphysics simulations of entrained flow gasification. Part I: Validating the nonreacting flow solver and the particle turbulent dispersion model. Energy Fuels 2012, 26, 451-463.

20. Kumar, M.; Ghoniem, A.F. Multiphysics simulations of entrained flow gasification. Part II: Constructing and validating the overall model. Energy Fuels 2012, 26, 464-479.

21. Abani, N.; Ghoniem, A.F. Large eddy simulations of coal gasification in an entrained flow gasifier. Fuel 2013, 104, 664-680.

22. Seggiani, M. Modelling and simulation of time varying slag flow in a Prenflo entrained-flow gasifier. Fuel 1998, 77, 1611-1621.

23. Ye, I.S.; Park, S.; Ryu, C.; Park, S.K. Flow and heat transfer characteristics in the syngas quench system of a 300 MWe IGCC process. Appl. Therm. Eng. 2013, 58, 11-21.

24. Hong, J.; Jeong, H.J.; Song, J.; Hwang, J. Numerical study on the 300 MW Shell-type one-stage entrained flow coal gasifier applied with 4-layer slagging model. Trans. Korean Soc. Combust. 2012, 17, 1-11. 
25. Hong, J.; Park, S.S.; Song, J.; Hwang, J. Numerical study on 300 MW Shell-type one-stage entrained flow bed gasifier: Effect of coal biomass blending ratio on $\mathrm{CO}_{2}$ gasification. Trans. Korean Hydrog. New Energy Soc. 2012, 23, 274-284.

26. Jeong, H.J.; Seo, D.K.; Hwang, J. CFD modeling for coal size effect on coal gasification in a two-stage commercial entrained-bed gasifier with an improved char gasification model. Appl. Energy 2014, 123, 29-36.

27. Ma, J.; Zitney, S.E. CFD modeling of entrained-flow gasifiers with improved physical and chemical submodels. Energy Fuels 2012, 26, 7195-7219.

28. National Energy Technology Laboratory, U.S. Government Printing Office. Cost and Performance Baseline for Fossil Energy Plants Volume 1: Bituminous Coal and Natural gas to Electricity; National Energy Technology Laboratory, U.S. Government Printing Office: Pittsburgh, PA, USA, 2010.

29. ANSYS Inc. ANSYS FLUENT User's Guide, Release 14.0; ANSYS Inc.: Canonsburg, PA, USA, 2011.

30. Silaen, A.; Wang, T. Effects of fuel injection angles on performance of a two-stage coal gasifier. In Proceedings of the 23th Annual International Pittsburgh Coal Conference, Pittsburgh, PA, USA, 25-28 September 2006.

31. Tomeczek, J. Coal Combustion; Krieger Publishing Company Inc.: Malabar, FL, USA, 1994.

32. Gomez-Barea, A.; Leckner, B. Modeling of biomass gasification in fluidized bed. Prog. Energy Combust. Sci. 2010, 36, 444-509.

33. Westbrook, C.K.; Dryer, F.L. Simplified reaction mechanisms for the oxidation of hydrocarbon fuels in flames. Combust. Sci. Technol. 1981, 27, 31-43.

34. Jones, W.P.; Lindstedt, R.P. Global reaction schemes for hydrocarbon combustion. Combust. Flame 1988, 73, 233-249.

35. Bustanmante, F.; Enick, R.M.; Killmeyer, R.P.; Howard, B.H.; Rothenberger, K.S.; Cugini, A.V.; Morreale, B.D.; Ciocco, M.V. Uncatalyzed and wall-catalyzed forward water-gas shift reaction kinetics. AIChE J. 2005, 51, 1440-1454.

36. Jess, A. Mechanisms and kinetics of thermal reactions of aromatic hydrocarbons from pyrolysis of solid fuels. Fuel 1996, 75, 1441-1448.

37. Turns, S.R. An Introduction to Combustion, Concepts and Applications, 2nd ed.; McGraw-Hill: Singapore, 2006.

38. Virks, P.S.; Chambers, L.E.; Woebcke, H.N. Thermal hydrogasification aromatic compounds. Adv. Chem. Ser. 1974, 131, 237-258.

39. Petersen, I.; Werther, J. Experimental investigation and modeling of gasification of sewage sludge in the circulating fluidized bed. Chem. Eng. Process. 2005, 44, 717-736.

40. Freund, H. Gasification of carbon by $\mathrm{CO}_{2}$ : A transient kinetics experiment. Fuel 1986, 65, 63-66.

41. Ni, J.; Liang, Q.; Zhou, Z.; Dai, Z.; Yu, G. Numerical and experimental investigations on gas-particle flow behaviors of the ppposed multi-burner gasifier. Energy Conver. Manag. 2009, 50, 3035-3044.

42. Eurlings, J.T.G.M.; Ploeg, J.E.G. Process performance of the SCGP at Buggenum IGCC. In Proceedings of the Gasification Technologies Conference, San Francisco, CA, USA, 18-20 October 1999. 
43. Choi, Y.C.; Park, T.J.; Kim, J.H.; Lee, J.G.; Hong, J.C.; Kim, Y.G. Experimental studies of 1 ton/day coal slurry feed type oxygen entrained-flow gasifier. Korean J. Chem. Eng. 2001, 18, 493-498.

44. Ash Fusion Temperatures. Available online: http://www.et.byu.edu/ larryb/Ash\%20Fusion\% 20Temperatures_1.html (accessed on 10 March 2015).

45. Bockelie, M.J.; Denison, M.K.; Chen, Z.; Linjewile, T.; Senior, C.L.; Sarofim, A.F. CFD modeling for entrained flow gasifiers in vision 21 systems. In Proceedings of the 19th Annual International Pittsburgh Coal Conference, Pittsburgh, PA, USA, 24-26 September 2002.

46. Elliott, L.; Wang, S.M.; Wall, T.; Novak, F.; Lucas, J.; Hurst, H.; Patterson, J.; Happ, J. Dissolution of lime into synthetic coal ash slags. Fuel Process. Technol. 1998, 56, 45-53.

(C) 2015 by the authors; licensee MDPI, Basel, Switzerland. This article is an open access article distributed under the terms and conditions of the Creative Commons Attribution license (http://creativecommons.org/licenses/by/4.0/). 